\title{
Karl Barth as a homilist
}

\author{
T F J Dreyer \\ Reformed Theological College \\ University or Pretoria
}

\begin{abstract}
Any tribute to Karl Barth as the most important theologian of the 20th century must show an awareness of the many facets of his work. He will long be remembered for his monumental contribution to church dogmatics. The inspiration for his dogmatics was his dilemma in preaching the Word of God. Preaching and proclaiming the Word of God were his main interests. This article attempts to analyse his homiletic stance, not only as an academic theory, but in relation to his own sermons. Finally, the importance of Barth's theology for preaching in a postmodern society is outlined.
\end{abstract}

\section{INTRODUCTION}

Barth's theological work can be epitomised in the following motto: Praedicatio quaerens intellectum - Intellego, ut vere praedicam! (Denecke 1989:190). Anyone who attempts to evaluate a theological oeuvre such as that of Karl Barth faces a vast challenge, one that should only be taken on with the greatest circumspection. The inspiration for the current undertaking comes from his work itself as a vast and rich source of theological thought and reflection which we can draw on and use most fruitfully, even in the homiletics of our own time. It is widely assumed and argued that Barth's theology arose from a crisis in the preaching of his time. Pieterse (1979:16) describes some of the internal struggle Barth went through as a young minister, because he felt as if he was merely pretending to step into the pulpit to proclaim the Word of God, and that was precisely what he could not do! Pieterse comments: "So worstel hy met hierdie vraag dat 'n mens tereg kan sê dat sy teologie uit die nood van die prediking gebore is". [And he wrestled with this issue so much that one can rightly say that his theology was born from a crisis in his preaching.] Berkouwer (1954:15) also claims that Barth's theology was inspired by his struggle with how to preach. For that reason he wanted to serve the church and its preaching by emphasising the triumph of grace. "Ihr Herz, die Mitte seiner theologischen Existenz, aber ist die Predigt. Hier liegen der biografische Ausgangspunkt, der theologische Sinn und das praktische 
Ziel seines Wirkens. Barths Lebenswerk ist recht eigentlich ein Predigt Werk" (Genest 1995:1). [But the heart, the centre of his theological existence, is the sermon. Here lie the biographical point of departure, the theological meaning and the practical purpose of his work. Barth's life's work is actually a sermon work.]

On the basis of these statements it is therefore reasonable to analyse Karl Barth's thought as it crystallised in his homiletics. Hence, this study focuses on Barth's homiletics. ${ }^{1}$ However, any reflection on homiletics remains mere theological gymnastics if it does not culminate in the practice of preaching. Throughout Barth's entire life as an academic he never stopped preaching. It has often been said that Schleiermacher, Luther and Calvin's theological work resulted in a lifelong preaching practice, and the same can be said of Barth (Genest 1995:1). He spent a few years preaching as vicar in the Safenwiler congregation, and then, as a professor, he preached occasional sermons in several congregations from 1921 to 1964. In the last seven years of his professorship, he regularly preached in the congregation of the Basel prison. The sermons from this last period are used as examples in this study, because they are a repository of his theological thought during the last phase of his life. The aim of this study is therefore to attempt to determine to what extent Barth's sermons correlate with his homiletic theory. This topic led to the title of this study: Karl Barth as a homilist. Karl Barth was also a man of his times, which implies that his theological thought cannot be understood independently from the milieu in which he found himself. It is therefore important to provide a brief sketch of some contours of the theology of his time before we can focus on his homiletics.

\section{THEOLOGICAL MILIEU}

The theology in which Barth (1886-1968) was trained has been described in various ways. It was the period of the high flowering of neo-protestantism, which reached its zenith in the liberal theology of the last half of the $19^{\text {th }}$ and early $20^{\text {th }}$ century. It is precisely in this theological field that Barth was trained, and that he wanted to distance himself from (Berkouwer 1937:190). For Barth, it was a difficult phase in his life, one in which he was to develop new insights via his theological thought and study that would bring him into opposition with his former teachers (cf Genest 1995:31-32). Kotzé (1963:112) categorises the thought of Barth's time as immanent thought, which reflects the idealistic

\footnotetext{
${ }^{1}$ The inspiration for most of Barth's theological work came from his preaching, but, considering the vast number of works he published on dogmatics and theology in general, he did not write an extensive homiletics. The final Homiletik (Barth 1966) was the result of a series of seminars that Barth presented in Bonn in 1932 and 1933 (Bromiley \& Daniels 1991:7).
} 
determination of a religious person within the limitations of his or her own emotional and intellectual life. In such an approach, human beings and their abilities are seen as the measure of all things.

The theology of this period has also been described as subjectiveanthropological, because human beings are the central focus of this theology (Van Niftrik 1949:22). Van Niekerk (1984:410-424) summarises Barth's theological struggle as a conflict between the analogia fidei and the analogia entis as the key to the possibility of what we can say about God. Barth (1970:39) himself typified $19^{\text {th }}$ century theology as religionistic, because its point of departure is a general revelation in which it is assumed that human beings are a priori religious beings. It is against this background that we must attempt to understand Barth's reactionary thought. He himself described his theology as a double protest: he was reacting, on the one hand, against Pietism and Rationalistic Modernism, and on the other, against Roman Catholicism. In both he did, however, find a remarkable objective similarity in that both attributed to human beings a place that belonged to God alone Schleiermacher to the pious, and Roman Catholicism to a holy and pure person - and in that this led to a loss of the liberty and the actuality of the Word of God. He argued that there was an objective contrast in the alternative between the complete and sole authority of a religious person, or the complete and sole authority of God and his Word (Kotzé 1963:113). With regard specifically to preaching, Pieterse (1979:17-18) highlights the following aspects that were problematic and with which Barth was confronted:

- $\quad$ At the time, historical criticism played a dominant role, with far-reaching results for the authority of the Word and how it is preached. A split occurred between historical and theological exegesis, between scientific theology and ecclesiastical preaching. Barth was deeply concerned about the fact that the historical method could really do only the spadework, and actually failed to come to a greater understanding and to help provide a better interpretation of Scripture.

- The discrepancy between the theology and the preaching of the time was intensified in the explicatio-applicatio scheme. This refers to a tension between exegesis and its application. Exegesis was all too often not designed to support preaching, but only focused on what in a Scriptural text was genuine and what was not. This led to a homiletic applicatio that functioned separately from the exegesis. 
- Neo-protestant theology relativised and eliminated the message of the sermon.

The central theological issue of Barth's time was in essence the question of how to understand the Scriptures, that is a hermeneutic issue. Barth attempted to find an answer to this issue that would serve what the church preached.

\section{THE FOUNDATIONS OF BARTH'S THEOLOGY WITH REGARD TO PREACHING}

When one explores the foundations of Barth's theology, one finds that Barth himself revealed these foundations when he indicated that he was concerned with the infinite qualitative difference between God and human beings. He does not recognise any human truth norm, only God's revelation. There is no human way to God (Barth 1952:16). This approach cuts off any possibility of an analogia entis at the source. He regards any quest for the revelation of God in the horizontal level of psychology, ethics or history, as many $19^{\text {th }}$ century theologians attempted, as complete folly and mere human pride. Human beings cannot control or claim revelation, but must constantly be reminded of it. Human beings do not have the innate ability to understand revelation. Only God can speak about himself. This revelation is very closely related to the incarnation of Christ, to the point of being identical with it. Only Jesus Christ can be called revelation in the true sense of the word. Without grace there is no question of revelation, because revelation and reconciliation are also identified with one another. In revelation the point is always personally connecting with the Living Word (Barth 1958:32). Revelation is always an act of God. Scripture and preaching are never revelation in themselves, but they can refer to and testify to revelation.

In preaching, it is therefore also important to look at Barth's view of the three forms of the Word, namely the Word incarnate in the revelation of Jesus Christ; the Word of God in the Bible as testimony of the original revelation; and the Word of God in the pronouncements of the church. Barth strongly emphasises that the Word of God can never be understood other than by the testimony of the Holy Spirit, brought about by an acceptance of faith. Human beings can only discover that the Bible is the Word of God through faith. The Word in all its forms is therefore never something that a human being can own or do with what he or she wants, but it is an act, a gift given by the grace of God, and it is an act that must be repeated over and over (Barth 1952:276). The Bible an sich is not the Word of God, but is human testimony of God's word, which can once again become the Word of God through the testimony 
of the Holy Ghost, in so far as God wishes to speak to human beings in that way. Barth criticised the church fathers because for them The Bible was not “... de inspiratie niet tot een telkens opnieuw door Gods actuele genadedaad inspireren van de Bijbelwoorden, maar tot een perfectum, een voldongen afgesloten feit, een geïnspireerdheid van de Schrift word ..." (Polman 1955:123) [the inspiration for an inspiring, each time afresh, through an actual act of God's grace, of the biblical words, but ... a perfectum, a fixed and complete fact, an inspiration of Scripture]. It is not a permanent attribute of the Bible to be the Word. It must always become the Word of God as a result of the actualising work of the Holy Ghost. Barth calls maintaining this principle the struggle for the sovereignty of the Word of God. Human beings are therefore never the masters of the Word, but merely its ministers or servants (Barth 1952:339). From a historical perspective, the Bible is seen merely as an ordinary human book that can be subjected to historical criticism. From a faith perspective, it is the Holy Ghost that makes the Bible the Word of God in people's hearts.

It is on this notion that Barth founded his view of the essence, authority, content and purpose of preaching. Preaching is the third form of the Word. Preaching takes places within a dialectic tension. Human beings, as sinners, cannot speak of or for God. For that reason, God himself stands in for what is preached, because only God can speak about God. The power of a sermon does not lie in the abilities of the preacher. No preacher dare ever, even after his very best sermon, claim that he has presented the Word of God, because the power of the sermon does not depend only on thorough exegesis, or on how well homiletic rules have been followed: it is only the Word of God if it pleases God to make it the Word of God through his Spirit so that people will believe it to be his Word (Barth 1952:73). Via the miracle of faith, the Word becomes a reality. It is therefore easy to understand why Barth emphasised the notion that the sermon and prayer are closely interwoven. Theology and preaching are only possible when they are carried by prayer, because prayer opens up the possibility that God will speak his Word through his Spirit (Cameron 1994:99). This point of view reflects Barth's attempt to overcome the subject-object scheme of the dualism between historical and theological exegesis, or scientific and practical interpretations of Scripture. In his view of Scripture, Barth attempted to show that God is not an objective phenomenon that can be turned into the object of scientific study, but that the object of theology was originally its subject and must again become its subject. It is in the sermon, the hearing and the understanding of the Word in faith through the working of the Spirit, that Scripture becomes the Word of God. Hermeneutics is therefore the route to bridge the gap. The hermeneutic 


\section{Karl Barth as a homilis}

method should therefore overcome the subject-object opposition (Pieterse 1979:24

Pieterse $(1979: 21,24)$ rightly argues that Barth as a transitional figure represents the end of the "old" hermeneutics and introduces a "new" hermeneutics. Because of his view of Scripture, Barth overcomes the subjectobject scheme, and hence bridges the duality between a "scientific" and a "practical" interpretation of Scripture (Lategan 1970:25). Although Barth in principle acknowledges the worth of historical-critical exegesis, he neglected these forms of exegesis in the practice of his own exegesis. He sought an alternative and found it in theological exegesis, but at the risk of losing sight of the historical aspects and of the dominance of seemingly eternally valid dogmatic truths. In his development of his hermeneutic thought, in his theological exegesis, he emphasised the importance of an understanding of Scripture for the present. He relativised the absolute objectivity of the person looking at the text because he operated on the two conscious assumptions that the church has, until the present, heard the Word of God in the Bible and that the exegete lives and acts in the expectation of hearing the Word of God for his time too. In this case his subjectivity gives him access to the issue in the text. "Want die objek van die ondersoeker in die Skrif was aanvanklik Subjek and moet weer Subjek word wat die subjek (ondersoeker) aanspreek" (Pieterse 1979:26). [Because the object of the one investigating Scripture was initially the Subject, and must once again become the Subject that speaks to the subject (the one reading the text).]

The few remarks above on the main threads of his theology have already begun to crystallise his thinking with regard to preaching. These broad strokes will provide a starting point for a more detailed picture of his homiletics.

\section{BARTH'S VIEW OF HOMILETICS}

For the purposes of this study, as a starting point for a discussion of his comments on homiletics, the focus will be limited to a text that summarises Barth's seminars on homiletics in Bonn in 1932 and 1933 (Barth 1966). This text encapsulates Barth's views in a nutshell. A brief overview of the text suffices to indicate its salient points.

\subsection{A definition of preaching}

In his introductory remarks, Barth discusses and criticises the definitions of preaching proposed by theologians such as Schleiermacher, Palmer and Fendt. Then he provides his own definitions. Barth (1966:30) presents two possible definitions: 
- The Predigt ist Gottes Wort, gesprochen von ihm selbst unter Inanspruchname des Dienstes der in Freier Rede stattfindenden, Menschen der Gegenwart angehenden Erklarung eines biblischen Textes durch einer in der ihrem Auftrag gehorsamen Kirche dazu Berufenen. ${ }^{2}$

- The Predigt ist der der Kirche befohlene Versuch, dem Worte Gottes selbst durch einem dazu Berufenen so zu dienen, dass im biblischer Text Menschen der Gegenwart als gerade sie angehend in freier Rede erklärt wird als Ankundigung dessen, was sie von Gott selbst zu hören haben. ${ }^{3}$

In his typically dialectical way, he described the dual nature of preaching: as coming from "above" when God himself speaks, and as coming from "below", as a human attempt of the church to give God a voice. From these definitions it is once again clear that preaching only becomes possible when the preacher himself is spoken to by God. Barth emphasised that a sermon is given in "freier Rede", in a kind of colloquial speech or "free translation" into words that people can understand. In doing so he implies that the preacher often says more than the text says, because the sermon includes the theological exegesis of the text aimed at human beings here and now. He also prefers the word "Ankündigung"4 [announcement], because a preacher can only announce what God wants to say and, as a human being, he should not pretend to possess and proclaim the Word of God. God himself will speak, and not the human being. Hence, a human preacher can only announce what God might want to say. Sermons are preached at the behest of the church and will therefore always be bound to the church, via the church official who is called and ordained to this office. Barth took the idea that preaching is aimed at people in the present very seriously. In his definitions, he attempts to break away from the views of Schleiermacher and others who wanted to base

\footnotetext{
2 "Preaching is the Word of God which he himself speaks, claiming for the purpose the exposition of a biblical text in free human words that are relevant to contempories by those who are called to do this in the church that is obedient to its commission" (according to the translation by Bromiley \& Daniels 1991:44).

3 "Preaching is the attempt enjoined upon the church to serve God's own Word, through one who is called thereto, by expounding a biblical text in human words and making it relevant to contemporaries in imitation of what they have to hear from God himself" (according to the translation by Bromiley \& Daniels 1991:44).

${ }^{4}$ Barth is often blamed for the fact that his decision to refer to preaching as an "announcement", could lead to an authoritative and one-sided view of a sermon ("outoritatiewe en eensydige preekopvatting") (Vos 1996:146; Long 1989:26).
} 
preaching in human experience. Barth shifts it into the framework of faith as a theological reality that points towards the divine reality.

\subsection{Criteria for preaching}

Based on his definitions, Barth (1966:32-69) compiled nine criteria for preaching. Some of these are discussed in some detail below.

\subsubsection{Connectedness with revelation}

Revelation is a closed circle in which God is the subject, the object and the mediator between both. Preaching cannot repeat and mediate that revelation. Therefore a sermon cannot be proof of the truth of God, but nor can it be a mere lecture on the Bible: it can only be a "saying after" the revelation. The revelatory aspect of a sermon is related to the coming and return of Christ. It is not merely the annunciation of a unique historical event, but of God's continued revelation of himself. It cannot preach only of what was and of what is, but must also speak of what is to come; it must speak of hope and expectation.

\subsubsection{Connectedness to the church}

The church is constituted by revelation; its very existence consists in repeating that revelation so that the essence and the existence of the church coincide. Only within the space of a congregation of God that has been called to it can a sermon be legitimately preached. Within the space of the congregation, the sermon and the sacraments are also interdependent.

\subsubsection{Connectedness with the confession}

Confession is being accountable, responding to what has been heard. "Die Predigt kann nicht anders geschehen als nach der Norm der in der Kirche geltenden Bekenntnisse. Jede Predigt kann nichts anderes sein als dem Akt der Verantwortung gegen den Ruf, eng angeschlossen an das Symbol" (Barth 1966:49). ${ }^{5}$

\subsubsection{Connectedness with the office}

The act of preaching, the congregation and the office are indissolubly linked. Barth emphasises the need to be called to the office by God as a prerequisite for taking that office, and the requirements imposed by Scripture on the

\footnotetext{
5 "Preaching cannot be done except according to the norm or the confessions that are recognised in the church. No sermon can be anything other than an act or response to the call, closely connected to the creed", according to the translation by Bromiley \& Daniels (1991:44).
} 
person who takes that office. He connects the notion of being capable of teaching with theological schooling as a prerequisite for preaching. In his preaching, a preacher cannot rely only on the Holy Ghost. He must do everything in his power to ensure that he conveys the Word in the right way while he believes and trusts that the Holy Ghost will make it possible and actual. For the congregation, the connectedness of the preacher to his office means that they will hear something about the matter of God from someone who is in God's service. Hence, the preacher is less important than and is secondary to the Word. Yet he need not shy away from speaking of himself in his sermon, but if he does so, he should do so precisely as a sinner who must in the first instance speak of himself, in solidarity with the congregation (Cameron 1994:101).

\subsubsection{Connectedness with the Bible}

Barth uses the term biblicity (connectedness with the Bible) to mean that a sermon interprets Scripture, but he does not see this as an interpretation of Scripture that is constrained by its own systematics. The interpretation should instead rather be sought in an attitude of openness in the preacher to receive the living Word of God from Scripture. He emphasises the importance of the text chosen for the sermon, because the congregation should not remember the sermon as much as the text on which it is based (Cameron 1994:100). The preacher must seek the Word of God for himself and his congregation in this historical document. The preacher must be humble enough to put his traits and insights aside when he is faced by the Word. Biblicity requires the preacher to be flexible enough to submit himself to the moving of the Word itself in this engagement and encounter with the Bible. Where Holy Scripture reigns like that, there can be no question of a class of priests or office bearers with an inflated notion of the importance of their mission, office and theological knowledge. In this sense of the connectedness of preaching with the Bible the "priest" cannot be self-assured and self-satisfied. This kind of connectedness with the Bible also prevents sermons from being boring, because when the living Word itself speaks, it is a new and exciting event every time. Barth sees the relation between the Old and the New Testament as a direct linear scheme of prophecy and its fulfilment.

\subsubsection{Originality of preaching}

In the criterion of originality, he creates some room for the uniqueness of each preacher. Each preacher is a human being with specific attributes who is called to fulfil this task. "This is what is meant by originality. Pastors are not to adapt a role. They are not to slip into the clothing of biblical characters .... 
They are simply to be themselves, and to expound the text as such" (Bromiley \& Daniels 1991:82). Barth also sees it as a prerequisite for the originality of preaching that the preacher himself should stand face to face with the congregation as one who has been moved by the Word to face judgement, to repent, to receive grace and to show gratitude. Originality requires a preacher to have the courage to say to others what the Word tells him now, to be someone who justly remains connected to the Bible, and who does not stop at exegesis but can truly testify to the Word.

\subsubsection{Connectedness to the community}

Preaching is always directed at the congregation of God. Christ died and was resurrected for these people; that are the truth which must be announced to them. Some conditions for this to be possible are that the preacher.

- must love his congregation;

- must know the real conditions in and circumstances of the congregation and must be able to capture these conditions in his sermons;

- must have enough tact to be able to recognise what in the current situation in the congregation should rather not be said;

- will not deliberately put his relationship of trust with the congregation at risk because of arrogance;

- the preacher must have the "kairos-awareness" to determine what the situation which we now share requires.

\subsection{Formal requirements for preparing a sermon}

Barth dedicated the last part of his homiletics to the requirements for preparing a sermon. The discussion in this article is limited to the most important of these requirements.

\subsubsection{Selection of the text}

Barth was wary of too much freedom in choosing a text because if a preacher has a free choice, he may be tempted to turn the text into a vehicle for his own ideas. The same risk applies if the text is too short, and is then used outside the wider context of the pericope. Instead, Barth advocated the use of prescribed pericopes or a series of sermons. However, he does allow for a preacher to be moved by certain parts of Scripture in his constant interaction with Scripture and to preach on those parts of the text. 


\subsubsection{Exegesis}

In his exposition of what exegesis involves Barth repeatedly highlighted the importance of the coherence of the text within its wider context (corpus). His sharp criticism of the absolutising of the historical-critical method is prominent. He was particularly outspoken in his rejection of the tendency of this method to take into account only human beings and their world as the only things that count. A sermon cannot be based on this "dogma" as an assumption. The "dogma" that should inspire a preacher is that the Word was incarnated. Barth rejected the formulation of a theme or scopus, because he believed that in the Bible there is only one theme, namely God's revelation in Jesus Christ. What the biblical text says is not itself the revelation, but human testimony of that revelation. A preacher cannot preach on a theme - at best, he can testify to the Revelation. Barth unapologetically emphasised the importance of dogmatics as a guide to an understanding of the Bible. It frees the preacher from arbitrariness and anchors him in his responsibility toward the confession of the church. Here we clearly see the theological exegesis that Barth advocated so strongly in his theology.

\subsubsection{Homiletic method}

The explicatio-applicatio dualism must be overcome by a unity in which both show to advantage in an integrated whole. Any exegesis (explicatio) that does not reach out to and resonate in those who listen to it from the start has no raison d'être. The preacher must constantly be active in the dialectic tension between a connectedness with the text and a connectedness with life. Exegesis is a corrective for the ideas used in the applicatio.

\subsubsection{Form of the sermon}

A sermon is a unit, from beginning to end, a whole, a "corpus". A forced division of the sermon into subsections disrupts the unity of the sermon. In the light of this formal requirement, Barth argued that a sermon should have no introduction or conclusion. He also rejected introductions because of his fear of the analogia entis that tries to find a point of connection in the human mind so that the Word can enter. He was also suspicious of the conclusion of a sermon that could tend to fall into the trap of the explicatio-applicatio dilemma, where the entire sermon becomes explicatio, and only the conclusion contains a brief applicatio. He rejected the illustrative use of examples in a sermon under all circumstances. 


\section{Karl Barth as a homilis}

\section{BARTH'S PREACHING IN PRACTICE}

Barth's preaching practice should be assessed against the backdrop of his theological and homiletic thought. For the purposes of such an investigation, two anthologies of Barth's sermons were chosen. Barth preached regularly in the Basel prison between 1959 and 1963. Marsch (in Barth 1959:8, 9) quite rightly comments as follows in the foreword to one of these anthologies:

I suppose that both critics and disciples have often wondered "How does this theology preach?" ... I think the question would be better put: "What sort or preaching lies behind this kind of theology?" Here the great theologian can be heard himself. In these sermons he speaks mainly to the inmates of a Swiss prison, for while Professor of Theology at Basel University, Karl Barth has exercised a truly remarkable hidden ministry, visiting and preaching regularly in Basel Prison. I think this congregation would put any man's theology on the test; for it is not easy to know what to say to men and women in prison, nor how to say it.

(Barth 1959:8, 9)

The limited scope of this article does not allow for a detailed discussion of each of these sermons. Only selections and quotes from both anthologies are therefore used to illustrate a number of the most noteworthy attributes of his preaching.

\subsection{Selection of the text}

Barth's choices regarding the texts he preached on reveal clearly that he was motivated by two main considerations to select those particular texts. First, he chose texts that are clearly relevant to the situation and existential crises of his prison audience. Second, the sermons themselves reveal that these were in all cases texts that spoke to him personally in his own existential situation. His homiletics create the impression that he strongly rejects too much freedom in the selection of a preaching text and that he is a proponent of a periscope system or a series of sermons. In practice, however, he allows himself the freedom to select a text that is appropriate to the situation and that really speaks to him personally. It is also noticeable that throughout the sermon he only announces short concise sections of the text to ensure the unity of the sermon. The short texts do feature in their wider context, but for the purpose of the sermon, only the essence is highlighted. The following texts adequately illustrate this principle in his sermons: Psalm 73:23 "Nevertheless I am continually with thee; thou dost hold my right hand" (Barth 1959:14); Ephesians 2:5 - "By grace have you been saved" (Barth 1959:3); 
Luke 23:3 - "They crucified him with the criminals" (Barth 59:76); Psalm 50:15 - "Call me in the day of trouble, I will deliver you, and you shall praise me" (Barth 1965:30).

In practice, Barth therefore allowed himself greater freedom of choice in his selection of preaching texts than his theory suggests. In his preaching practice, the power and current relevance of his sermons lie precisely in the fact that in his selection of a preaching text, he continually bears in mind the situation of his listeners. Although in his homiletics he cautions preachers against using texts that are too short, because they pose the risk that the short text can become a mere peg for the preacher to hang his ideas on, Barth's own sermons repeatedly reveal that he tends to focus on one short central idea in the text. It is this concise central focus that unifies his sermons and that provides the cohesion that makes his sermons so striking.

\subsection{Sermons as proclamations of God's salvation here and now}

In his homiletics, Barth is a proponent of sermons as an announcement rather than as a pronouncement. When one reads his sermons, one gets the impression that he means this much more strongly than the word "announcement" initially suggests. In those listening to his sermons, his sermons create a sense of listening to a powerful proclamation of and appeal in the Name of God:

Do you know for whose sake he is hanging there? For our sake because of our sin - sharing our captivity - burdened with our suffering! He nails our life to the cross. This is how God had to deal with us. From this darkness he has saved us. He who is not shattered after hearing this news may not yet have grasped the word of God! By grace you have been saved!

(Barth 1959:38)

His sermons are a proclamation of the sovereign God, not as an historical event or as a vague promise about which one can philosophize, but as a reality, an event, a revelation here and now:

I have conquered the world, we hear. Not, I shall do it some day! But: It is finished, it has happened. I have done it. All you need to know is to notice, and to get ready to accept the fact, that you are living in a world conquered by me - and you are already men conquered by me.

(Barth 1965:107) 


\section{Karl Barth as a homilis}

From these two examples from his sermons it is clear that he manages to break out of the object-subject dualism because he himself feels as if he is spoken to as a subject by the true Subject and becomes the object of this encounter with God. It is on the basis of this hermeneutic happening that his preaching becomes the living Word of God which speaks to people for itself. The genuineness of his sermons is situated precisely in the way he has lived through and wrestled with issues in his own faith.

\subsection{Style of the sermons}

With a theologian of Barth's stature, one expects to see some signs of his vast erudition, knowledge and learning in his sermons. However, one finds the opposite. His sermons reveal a simplicity and clarity that make it possible for ordinary people to understand them. There are no complex theological arguments and there is no academic dogmatising, but simply a theology and dogmatics that are so thoroughly integrated with his life in the faith that it is free from any hint of academic pomposity. Throughout he maintains a dialogical style because he enters into a dialogue with his listeners, and he anticipates their possible questions and their situation and he keeps them interested in what is happening in the sermon: "But is there such a thing as this? you may well ask me. How are we to imagine it?" (Barth 1965:25). "Someone once said to me: 'I need not go to church. I need not read the Bible. I know already what the church teaches and what the Bible says ....' If this were the message at stake, I would most certainly not have come here. My time is too precious and so is yours .... Anybody is at liberty to say this to himself" (Barth 1959:36).

It is clear throughout his sermons that he himself is also moved and feels as if the words speak to him too. He too is clearly affected by the words as an event, and sometimes he even says so explicitly: "Let me tell you quite frankly: we are all together great sinners. Please understand me: I include myself. I stand ready to confess being the greatest sinner among you all ..." (Barth 1959:37).

\subsection{The relationship between explication and applicatio}

In line with what he advocates in his homiletics, in his sermons he does indeed manage to overcome this dualism and to unite these two strands. From beginning to end, his sermons are an applied explication. Nowhere in his sermons will one find a loose or unconnected exegetical passage. His sermons are proof that his exegesis only served to enhance his own understanding of the text, and the results of his exegesis are worked into the sermons in such a way that the sermon is directed at the congregation as 
kerygma, as the living Word of God, from the outset. This does not imply that he neglected his exegetical work in the least, but that he wove the results of his careful exegesis into the sermon so successfully that they became a perfect unit. His theological exegesis, what he calls "freie Rede" in his sermons, is reflected in his preaching. On the basis of his theology and dogmatics, in his sermons he goes beyond the text. He announces the text in its context of the totality of the Revelation.

\subsection{Connectedness with the congregation and the situation}

One of the criteria Barth proposed for preaching is a connectedness with the congregation. Barth is often unjustly accused of not taking into account modern human beings in their context (Pieterse 1979:28; Long 1989:26). His sermons prove the opposite. He always bears in mind human beings and their situation. He also does not fall into the error of philosophising about his time in an abstract manner, but speaks from a rootedness in the concrete reality.

That is one sort of trouble which cannot be covered up, let alone cured: either by Carnival or by the trade Fair or by a jubilee if one is due once again - or by the grandest Olympiad, or by communism, or anti-communism, or by Moral Rearmament as they practise it at Caux on Lake Geneva or by evangelical campaigns like the one we recently had in Basel ....

(Barth 1965:32)

Last week a Christmas meditation appeared in the National Zeitung - perhaps one or other of you has read it - in which we were reminded that in the past year man had succeeded in reaching the moon. Nothing could now cancel or alter the fact that the Russians had sent a disinfected capsule up there and now there it is ...

(Barth 1965:14, cf also Cameron 1994:102-103).

In his sermons, Barth remains a human being of his time with his feet planted squarely in his world, but he is also open to and understanding of the distress of his time.

\subsection{Introductions and conclusions}

Fearing the analogia entis, Barth rejected any form of introduction to a sermon that is based on the notion that there is a point of departure for the Word in any human. However, in his sermons, he himself often uses an introduction to engage the attention of his listeners from the start. So, for example, he starts a sermon about Psalm 50:15 with the following introduction: "Call me, we 
read. That reminds me at any rate of someone 'calling' me on the telephone that is, and interrupting and disturbing me at my work, or in the middle of a conversation or perhaps when I am just about to listen to some music ...." (Barth 1965:30).

He starts a sermon on Psalm 31:15 by telling his congregation about a friend of his who was a professor in France, which immediately intrigues the listeners and engages them in what he wants to say by means of questions. $A$ last example is this: "During the week I read a sentence in the Migros newspaper ... which I expect you know. It was an article entitled 'Prisoner's Christmas"' (Barth 1965:68).

In each case, the introduction is successful and effective, even though he cautions against the use of such introductions in his homiletics. His sermons reveal that as long as a preacher is aware of the risks involved in an irresponsible use of an introduction, it can still be used very fruitfully. He also rejects the use of a conclusion, because it is often used to present a loose application tagged on at the end of some exegesis - he does indeed avoid such conclusions, because his sermons are applicable throughout. However, he does use the end of his sermons to present a climax containing the key ideas of the sermon: "And how would it be, if, tomorrow morning, when we awaken, we were to say, again aloud or softly, exactly the same thing: 'My time is secure in your hands'? ... What a beginning to the year! Yes, what about it? What about that for an ending, what about that for a beginning! Amen" (Barth 1965:47).

\subsection{The use of illustrative material}

In his homiletics Barth strongly rejects the use of images, examples and stories as illustrations. However, his sermons are full of such illustrative material and the interweaving of such detail is precisely what gives his sermons their concreteness and what makes them so easy to understand: "... just as we give a patient an injection - or he gives one to himself. The illness, it is true, will not be cured, but at least the pain will be alleviated for a while" (Barth 1959:54).

There are many such examples in his sermons where he uses illustrative material very effectively. This is another discrepancy between his homiletic theory and his preaching practice.

\section{THE RELEVANCE OF A CONTEMPORARY HOMILETICS}

Bohren (1980:36-43) has described the dilemma of preaching as the "speechlessness" of the church. In his opinion, this "speechlessness" can be ascribed to the fact that the church is proclaiming a historical God who acted 
in the past (a set revelation). Texts from the past are repeated like a fixed repertoire, and preachers are therefore often unable to get God to speak in the present. He was a student of Karl Barth, and he felt that Barth's theology gave him the hermeneutic key to overcome this "speechlessness". Barth is indeed a transitional figure whose views of Scripture and whose dynamic understanding of revelation pioneered a new hermeneutics and homiletic theory. His theology can justly be described as a theology of proclamation, but he does not support proclaiming a set and congealed revelation, but proposes proclaiming a dynamic event in which God speaks here and now too (Hart 1995:81-82). According to Barth, revelation rises above the object/subject dualism and revelation is never complete or finished: "... for the relationship between God who is giving Himself to be known, and the human 'subject' who is receiving the capacity to know God is a continuing relationship: it has to be 'new every morning' or it is not knowledge or God at all" (Baxter 1986:35). The three forms of the Word of God as he describes it, namely Jesus Christ as the primary Word of God, the Bible as testimony of the revelation as the second form and preaching as the third form, open up new possibilities for a homiletic theory. Preaching then becomes a living confession of the revelation in Jesus Christ (Hart 1995:84-90).

In his discussion of the problems associated with preaching in a postmodern context, Lose (2003:63-111) focuses precisely on this view of the sermon as a confession. Wittekind (2001:344-371) discusses the history of reception theory and its effect on preaching and theology when it is applied to individual faith. He concludes that Barth's theology opens up the possibility of understanding and justifying diversity in a postmodern context and of accommodating it in preaching a sermon.

\section{CONCLUDING REMARKS}

It is impossible to evaluate the vast and comprehensive oeuvre of a theologian such as Karl Barth in the limited scope of a single article. This article was therefore merely an attempt to highlight a few aspects of Karl Barth as a homilist. A number of points emerged clearly:

- Designing a theory and method for preaching is one thing, but always applying that theory and that method consistently in practice is another. This problem can also be seen in Barth's work. Perhaps one can understand this discrepancy somewhat better if one acknowledges that every responsible theologian and teacher must warn his students of the risks and potential error in the strongest possible terms, but may also, as a responsible preacher, use some of the things that he warns his 


\section{Karl Barth as a homilis}

students against in his own sermons, precisely because he knows which traps to avoid.

- The lasting impression left by Barth as a homilist is that his sermons are not a mere academic-exegetical dissection of a historical text - his preaching is an event, an encounter with the living Word of God here and now. He displays the homiletic courage to take the risk of proclaiming the salvation of God to the people of his time. It is perhaps precisely this lesson that we can learn from him in our time, namely that we should not focus on the historical text, the author, the independent corpi, to such an extent that the living God can no longer speak through the sermons that we preach.

- The simplicity of this great theologian's style when he presents the Word should encourage us as aspiring theologians and academics to return to a much greater simplicity in our own sermons.

- Barth shows the compassion, piety and love for the flock of the Lord to whom he preaches to such an extent that it confirms his calling as a minister of the Word.

- As a transitional figure, in his views of Scripture and his thinking about revelation, Barth hermeneutically pioneered ways of preaching in a postmodern context.

Finally, one point keeps on recurring: in Barth's theology, he is not interested in theological fireworks or academic interests, but in the vital seriousness of his being a sinner before God and the joyous gratitude for his redemption in Jesus Christ. This is why his sermons are sincere, convincing and moving.

\section{Works consulted}

Baxter, C 1986. The nature and place of Scripture in the Church Dogmatics, in Thompson, J (ed), Theology beyond Christendom. Allison Park, PA: Pickwick. Barth, K 1952. Kirchliche Dogmatik, 1(1). Zurich: Zollikon.

Barth, K 1958. Kirchliche Dogmatik,. 1(2). Zurich: Zollikon.

Barth, K 1959. Deliverance to the captives. London: SCM.

Barth, K 1965. Call for God. London: SCM.

Barth, K 1966. Homiletik: Wesen und Vorbereitung der Predigt. Zurich: EVZ.

Barth, K [1956] 1970. The humanity of God. 9th ed. Richmond, Vi: John Knox Press. Berkouwer, G 1937. Karl Barth. Kampen: Kok.

Berkouwer, 1954. Triomf der genade in de theologie van Karl Barth. Kampen: Kok. Bohren, R 1980. Predigtlehre. München: Kaiser Verlag. 
Bromiley, G W \& Daniels, D E 1991. Homiletics - Karl Barth. Kentucky, KY: John Knox.

Cameron, C M 1994. Karl Barth - The preacher: The Evangelical Quarterly, 66, 99106.

Denecke, A 1989. Gottes Wort als Menschenwort: Karl Barths Predigtpraxis - Quelle seiner Theologie. Hannover: Lutherisches Verlagshaus.

Genest, H 1995. Karl Barth und die Predigt. Neukirchener: Neukirchen-Vluyn.

Hart, T 1995. The Word, the words and the witness: Proclamation as divine and human reality in the theology of Karl Barth. Tyndale Bulletin 46, 81-102.

Kotze, G J 1963. Hedendaagse Skrifprediking: 'n Ondersoek na die mistastinge in die prediking van die nuwere tyd. Potchefstroom: Pro Rege.

Lategan, B C 1970. Hermeneutiek en geskiedenis. Neotestamentica 4, 19-40.

Long, T G 1989. The witness of preaching. London: John Knox Press.

Lose, D J 2003. Confessing Jesus Christ: Preaching in a postmodern world. Grand Rapids, MI: Eerdmans.

Pieterse, H J C 1979. Skrifverstaan en prediking. Pretoria: NG Kerkboekhandel.

Polman, A D R 1955. De Theologie van Augustinus: Met Woord Gods bij Augustinus. Kampen: Kok.

Van Niekerk, A A 1984. Analogia fidei teenoor analogia entis: Karl Barth en die verstaanbaarheid van ons spreke oor God. NGTT 25, 410-424.

Van Niftrijk, G C 1949. Een beroerder Israels. Nijkerk: Callenbach.

Vos, C J A 1996. The volheid daarvan, I. Pretoria: RGN.

Wittekind, F 2001. Karl Barth und die moderne Predigt. ZThK 98, 344-371. 